\title{
Compositional Changes in Public Expenditure and Economic Growth: Time Series Evidence from Pakistan
}

\begin{abstract}
Ibrar Hussain ${ }^{1}$, Zahoor Khan', Muhmmad Rafiq ${ }^{3}$
Abstract

The role of government in achieving economic growth through its fiscal policy, particularly spending policy cannot be overlooked. Investigation of public spending policy and its transmission mechanism to sustainable growth is imperative to the ultimate objective of welfare maximization. This study aims to identify the growth-oriented components of public expenditure as it seems useful to know the contribution of each component of spending towards the objective of economic growth. The study adopts the Kocherlakota and Yi's (1997) model as modified by Colombier (2008) to carry out the empirical analysis. To this end, ARDL is employed on annual data that ranges from 1973 to 2014 to estimate both the long-run and short-run dynamics between public expenditure composition and economic growth in Pakistan. The results indicate that public development expenditures are growth-oriented, while current expenditures reduce economic growth. Thus sustainable economic growth and sustainable development can only be materialized by changing the composition of public spending in favor of development expenditure. Since Pakistan is in the dire need of infrastructure and energy, therefore, allocation of more funds to Public Sector Development Programs (PSDP) are expected to add directly to growth on one hand and set a crowding-in effect for private investments-thereby enhancing growth indirectly-on the other hand.
\end{abstract}

Keywords: Economic growth, composition of public expenditure, ARDL.

\section{Introduction}

The subject of public finance and fiscal policy is one of the most debated and talked about issues not only in the sphere of those who are directly concerned with it like economists (see for instance, Musgrave \& Musgrave, 1973; Atkinson \& Stiglitz,

1 Assistant Professor, Department of Economics, University of Malakand.

2 Assistant Professor, Institute of Management Sciences, Peshawar. Email: zahoor.khan@imsciences. edu.pk

3 Assistant Professor, Institute of Management Sciences, Peshawar. Email: muhammad.rafiq@imsciences.edu.pk

\begin{tabular}{|c|c|c|c|}
\hline \multicolumn{4}{|c|}{ ARTICLE HISTORY } \\
\hline 13 Oct, 16 & Submission Received & 8 Nov, 16 & First Review \\
\hline 21 Nov, 16 & Revised Version Received & 13 Dec, 16 & Second Review \\
\hline $19 \mathrm{Dec}, 16$ & Revised Version Received & 5 Jan, 17 & Accepted \\
\hline
\end{tabular}


1976) politicians, academicians and geographers (see for instance, Bennet, 1980), but also in the general public across the world. Economists normally develop models to analyze public spending and often deal with the efficiency of such spending; however, geographers on the other hand tend to derive the implications of public finances for regional developments across the world (see for example, Porteous, 1995). The role of government in influencing the lives of the people through its socio-economic policies cannot be denied in the present era. The range of economic policies is not even large, but also diverse and often very complex in nature (Tanzi, 2006). There is a general belief that the prime objective of public policy is the promotion of economic and social welfare. Economic prosperity, however, by and large depends on economic growth and in this regard not only the analysis of the size of public expenditure is important, but also its composition seems to play a crucial role in formulating longterm economic policy (Colombier, 2011).

Theoretically, the effect of fiscal policy on economic growth is divided in to two aspects that are expenditure and tax policies (Tanzi \& Zee, 1997). Taxation is generally considered as distortionary and influences economic behavior thereby creating inefficiency in the allocation of resources in situations when lump-sum levies are not feasible and as a consequent retards economic growth (Schaltegger \& Torgler, 2006). On the other hand, public expenditure can result in both crowding-in effect in the form of positive externalities arise from the provision of public goods and crowding-out effect in the form of decline in private production and investment (Schaltegger \& Torgler, 2006). It is obvious that fiscal policy plays imperative role in different regions, depending on the structure of both revenue and spending sides, but the problem is that regional patterns of both expenditure and revenue are unknown in majority countries (Blažek \& Macešková, 2010).

The revival of interest in growth theory in the decade of 1990's has led to the increasing interest of researchers in understanding and verifying the effect of fiscal policy on economic growth. As a consequent, a substantial volume of empirical research has been directed towards identifying the growth oriented elements of public spending (Bose, Haque, \& Osborn, 2007). One of the aims of public finances is to effectively allocate public resources according to the priorities setting of a society and these priorities normally include sustainable economic growth, full employment, competitiveness and social cohesion in the European context as compared to other societies (Magdalena, Logica, \& Zamfiroiu, 2015). However, Barrios and Schaechter (2008) are of the opinion that the size of the public sector that reflects political choices do not necessarily aim to accelerate growth and may have goals like income distribution or social cohesion to pursue via public spending. In such situations, the size and composition of government spending is expected to depend on the objective 
considered as priority by the society. If the composition of public spending is biased towards "productive" expenditures, this implies that society is giving priority to economic growth over other objectives like redistribution or social cohesion. Social and electoral preferences in democratic societies, determine both the size and composition of public expenditure and evolution in the latter will depend on changes in the former. Consequently, it can be deduced that countries with similar sizes and structures of public spending will have similar social preferences on the objectives of public finances and convergence in social preference would lead to convergence in both the size and composition of public spending (Ferreiro, Valle, \& Gomez, 2012). However, the efficiency with which the government provides public goods to achieve economic and social objectives is important, not only in the debate on government size and the role of private sector in this regard, but is also imperative for both macroeconomic stability and growth (Gupta \& Verhoeven, 2001).

While, the size of government defined as the ratio of its total spending to GDP is an issue of public-choice, its composition is open to debate (Devarajan, Swaroop, \& Zou, 1996). Some studies (see for example, Magdalena et al., 2015) reveal that the composition of public expenditure influences the performance of public sector and in this regard the share of non-discretionary expenditures determines the room for governmental maneuvering. Similarly, it also reveals the priority setting of a society in the long run. Furthermore, the effect of government size on well-being would depend on the level of trust of the general masses in the effectiveness of government and interesting insights can be gained by analyzing the composition of public spending that are characterized by strong redistributive effects (Boadway \& Merchand, 1995). Several authors distinguish between 'productive' and 'unproductive' government spending; show how a country can accelerate its growth by just changing the mix in favor of the productive spending (Devarajan et al., 1996).

Pakistan, like many developing countries, is experiencing fiscal strains due to continued security issues, flood related expenses, greater than target subsidies and global financial crises (Economic Survey of Pakistan, 2012-13). On the one hand, the fiscal managers often fail to mobilize domestic resources to accelerate economic growth that is why tax to GDP ratio is on the decline over the past few years and remains approximately $9 \%$ of the GDP. While on the other hand, the composition of public spending is not that optimal; with development expenditure is on the decline and current expenditure on the rise. In recent years, fiscal adjustment has been on the expenditure side of the budget, as defense expenditure over the past ten years has surged up due to war on terror and the country is therefore in dire need of spending on social services such as education, health and infrastructure. Although, public expenditures are considered as effective tool of accelerating economic growth 
via physical and human capital formation, in Pakistan, however, government expenditures remained under immense pressure during the past five years (ESP, 2012-13, Afridi, 2016)

The purpose of this study is to empirically estimate the impact of compositional changes in public expenditure on economic growth in Pakistan on the one hand and the impact of size of over all public expenditure on growth on the other hand. However, in this study the focus is to identify the growth-oriented components of public expenditure as it seems useful to analyze the contribution of each component of spending towards the objective of economic growth on the pace of fiscal constraint in Pakistan. The current study is categorical in empirical sense in that it takes government expenditures as consumption (unproductive) and development expenditure (productive) as reported in annual budget statements of government of Pakistan. While the study adopts Kocherlakota and Yi's (1997) model as modified by Colombier (2008) to carry out empirical analysis with slight modification based on the availability of the relevant data and to fulfill the requirement of co-integration relationship between dependent and a set of variables of our interest. The modification made in this study includes the use of growth of government current and development expenditure instead of using them in log form only. This modification enabled us to employ Auto Regressive Distributed Lag (ARDL) model ${ }^{4}$ to test long run relationship between dependent and a set of explanatory variables. The contribution of the study to the existing empirical literature on public spending-growth nexuses in a developing country like Pakistan is that only changes in the composition of government expenditure in favor of capital spending can accelerate growth in the pace of fiscal constraints. Mobilization of domestic resources does not seem an easy task in a developing country like Pakistan with large exemptions from taxes along with corruption and lack of political will. Therefore, the policy to increase the volume of public budget from year to year is simply wastage of resources and is not expected to add to the ultimate objective of sustainable growth in the country. Beside this the study highlights the relative efficiency of private investment as compared to public investment and shows the overall negative impact of government size on economic growth in the country. However, the analyses done in this study are categorical in nature, and one need non-categorical analyses to identify the most efficient and growth-oriented components of public spending. Similarly, comparative analysis of the efficiency of public-private capital spending would be needed in identifying the proximate causes of the poor performance of public investment outlays in Pakistan.

The remainder of the paper is organized as follows: section 2 reviews the relevant

4 See Section 3 for more details. 
literature and presents theoretical framework; section 3 sheds light on Pakistan's fiscal policy review; section 4 is allocated to data and econometric models; section 5 presents empirical findings based on the models in section 4 . Section 6 concludes and presents policy recommendations in light of the empirical findings.

\section{Review of Literature and Theoretical Framework}

There exists a wide body of literature on the relationship between public expenditure and economic growth, however, empirical findings using cross sectional analysis are mixed (Schaltegger \& Torgler, 2006). Inspecting empirical literature, researchers have used various approaches to analyze the relationship between public investment and economic growth. Some studies (see for instance, Costa, Ellson, \& Martin, 1987; Deno, 1988) that employed the production function approach arrive at the conclusion that public investment is not only an important ingredient of the production process, but also complements to the private investment. Milbourne, Otto, and Voss (2003) making use of the Mankiw, Romer, and Weil's augmented Solow-Swan growth type model, observe no significant impact of public investment on the level of output per worker in the steady state while find significant effect of public investment on economic growth in transition to the steady state.

Researchers have been interested in analyzing economic growth and its determining factors over a long period of time (Chamorro-Narvaez, 2012) and classified growth models into two broad categories: the neoclassical (Solow, 1956; Swan, 1956) and endogenous growth models (Romer, 1986, 1990; Lucas, 1988). According to the neoclassical growth model, fiscal policy has no growth effect at all, while endogenous growth models of 1990s admit a positive role in this regard via either changes in taxes or government expenditure decisions (Barro \& Sala-i-Martin, 1992). Empirical studies are likely to reject neoclassical growth model's prediction related to fiscal policy and indicate that public expenditure particularly capital spending has long run impact on economic growth (Aschauer, 1989; Haque \& Kim, 2003). It is therefore evident that analysis of the components of public spending is imperative than the total size of government spending (Chamorro-Narvaez, 2012). There seems a lack of consensus in theoretical literature regarding the impact of fiscal policy on economic growth.

The impact of compositional changes in public spending can theoretically be traced in public-policy endogenous growth models (PPEGMs) which are based on endogenous growth theory (Ferreiro et al., 2012). Long run economic growth, according to PPEGMs, can be accelerated by switching public spending from unproductive to productive forms and taxation from distortionary to non-distortionary forms (Barro, 1990; King \& Rebelo, 1990; Gemmell \& Kneller, 2001; Irmen \& Kuehnel, 2009). However, the impact of public investment on economic growth is largely unsettled and 
is to be determined (Ghani \& Din, 2006). One view regarding the positive impact of public investment on growth argues that public investment provides stimulus to private investment as it enhances the productivity of private investment thereby accelerating economic growth (see for example, Arrow \& Kurz, 1970; Barro, 1990). The positive spillovers of public investment, according to this view stem not only from the provision of education, health, infrastructure and research \& development, but may also accelerate growth via crowding-in effect on private investment (Ghani \& Din, 2006).

The theoretical prepositions on the impact of public spending composition on growth has largely originated from empirical findings and extensive empirical studies on endogenous models resulted in the decomposition of public spending into productive and consumption components (Olabisi \& Oloni, 2012). Productive expenditures are assumed to be growth-oriented, while consumption component negatively affects growth (Aschauer, 1989; Barro, 1991). However, marginal efficiency of fund falls with allocation of excessive amount for productive purposes (Devarajan et al., 1996). But the question is which expenditure is productive and which is unproductive? Existing literature lacks consensus on the issue in this regard (Barro \& Sala-i-Martin, 1995; Musgrave, 1997).

Empirical studies that analyze the relationship between economic growth and composition of public spending are broadly divided into two groups, i.e. categorical and non-categorical (Olabisi \& Oloni, 2012). The former category groups public expenditure into "productive" and "unproductive" prior to its analysis, while the latter lets the data and the results to differentiate productive components from unproductive ones. According to some authors (Aschauer, 1989; Barro, 1991; Easterly \& Rebelo, 1993) public consumption that enhances households' utility function are termed as unproductive as they are expected to reduce growth via tax distortion and will lower the incentive to invest by the private sector. On the contrary, public consumptions that encourage and complement productive activities in the private sector are regarded as productive expenditure and the example of such expenditure is infrastructure spending. Most of the cross sectional studies, however, agree only on grouping public expenditure into productive and unproductive, but usually disagree on which component is to be included in productive and which not (Olabisi \& Oloni, 2012).

Using meta-analysis, Nijkamp and Poot (2003) examined the robustness of evidence on the fiscal policy growth nexuses. The study took 93 published studies and made use of several meta-analytical techniques such as contingency table analysis, descriptive statistics and rough set analysis on five areas of fiscal policy including general public consumption, infrastructure, education and defense expenditure and the tax rates. The study showed a weak positive impact of conventional fiscal policy on 
economic growth. It however confirms that education and infrastructure expenditures are growth-oriented. The study also indicates towards the sensitivity of the results of different studies and attributes it to the problems of data type, specification of the underlying models and econometric techniques.

Overman and Van Thiel (2016) identified different aspects of public sector performance including efficiency, effectiveness, compliance, implementation, quality, meeting standards of good governance, sustainability, and so on. It is evident that productivity of public expenditure plays important role in both fiscal adjustment and its sustainability, particularly in situations when the government has limited resources at its disposal to support public services. In situation of fiscal strains, only focusing the revenue side of fiscal policy would not lead to the optimal solution and focusing on the productivity of public expenditure seem a viable option to reduce fiscal deficit or to expand critical expenditure programs (Chu, Davoodi, \& Gupta, 2004).

Wang and Wang (2014) analyzed the effectiveness of both the size and structure of Chinese public expenditure on the welfare of general citizens. Using static and dynamic binary response model on a panel data, their result shows that though public expenditure in China is not oversized, however, its composition is not efficient and in some fields funds are less efficiently utilized. Colombier (2011) in case of Swiss estimates the effects of government expenditure composition on economic growth and finds expenditures on education, administration, transport and infrastructure as growth-oriented. Schaltegger and Torgler (2006) find negative relationship between government size and growth in case of Switzerland over a period of 1981-2001. The study however, shows an insignificant effect of capital spending on economic growth in contrast to consumption spending. Barro (1991) in his influential work on the subject finds negative impact of public sector on economic growth in a large sample of cross-section countries. Similar relationship is also confirmed by other studies (Folster \& Henrekson, 2001; Romero de Avila \& Strauch, 2003; Schaltegger \& Torgler, 2006). However, many authors are skeptical about the robustness of the results of such studies that have found the negative relationship between the size of public sector and growth (see for instance, Atkinson, 1995; Agell, Lindh, \& Ohlsson, 1997, 1999).

\section{Pakistan's Fiscal Policy Review}

Much of the research work done on fiscal policy is naïve and underdeveloped in Pakistan. Growth experience in Pakistan has not been sustainable and often witnessed occasional spurts. Different studies (see for instance, Zafar \& Mustafa, 1998; Ghani \& Din, 2006; Mehmood \& Sadiq, 2010; Qasim, Kemal, \& Siddique, 2015) covered different aspects of fiscal policy by using different models. Since, economic growth is determined by policy actions both in the form of discretionary demand management 
policies and supply sides actions. Hence, it seems quite difficult to isolate the effect of fiscal policy on a country's economic performance. Many insightful studies exist (such as Birchwood \& Matthias, 2007; Barnes, 2008; Alam, Sultana, \& Butt, 2010; Aarle, 2013; Barbiero \& Cournède, 2013) on the aspects of fiscal policy that mostly rely on cross-national and cross-sectional analyses. Meanwhile, most of the existing studies that deal with the experience of developed nations do not effectively capture the contextual fiscal management of the developing world and therefore, cannot be blindly extended to a developing economy like Pakistan.

Ghani and Din (2006) in case of Pakistan, using vector autoregressive (VAR) approach show that private investment is more growth-oriented than public investment and consumption. But, some studies like that of Hyder (2001) and Naqvi (2002) point towards the complementarities between public and private investments in the country. While investigating the impact of public spending on growth, Looney (1995) identifies that public non-infrastructural investment does not set a real crowding-out effect for private investment in the presence of large manufacturing sector. Similarly, Hyder (2001) using the vector error-correction framework tests the crowding-out hypothesis for Pakistan points towards the complementarities between public and private investment. Besides Hyder (2001), Naqvi (2002) analyzes the impact of public and private investment on growth via VAR methodology and identifies that past public investment has positive impact on current private investment in Pakistan.

Khan (1996) in a study of a large group of developing countries also shows the growth driven role of private investment as compared to public investment. Mehmood and Sadiq (2010) investigated both the long run and short run relationship between government spending and poverty and found negative relationship between the two via Johanson co integration method. The study used over all fiscal deficits a proxy of government expenditure and did not provide a disintegrated analysis of public spending as not all spending are expected to be growth-oriented. Similarly, the application of the model does not seem appropriate for a sample of thirty five observations. Zafar and Mustafa (1998) however find a negative impact of fiscal deficit on growth and conclude that public deficit reduces GDP through distortionary taxation and excessive consumption expenditure that crowd-out private investment. In another study by Yaya (2010) in a panel of six countries find mix results. The study finds negative relationship between fiscal deficit and growth for three countries, while finds no evidence of any causal relationship between the two. However, panel studies often fail in investigating such phenomena due to specific characteristics of each country in the analysis. 


\section{Data and Econometric Model}

To estimate the long run and short-run relationship between the composition of public spending and economic growth and between the size of public spending and growth in Pakistan, time series data were obtained from various issues of Economic Survey of Pakistan, Hand Book of Statistics by State Bank of Pakistan and World Development Indicators (WDI) by World Bank. The data are annual and span the time period 1973 to 2014. See Table 1 for more details:

Table 1: Variables' Definitions, Measurement and Data Sources

\begin{tabular}{|c|c|c|}
\hline Variables Definition & Measurement & Data Source \\
\hline GDP Per Capita & $\begin{array}{l}\text { Constant Local Currency Unit } \\
\text { (Rupees) })^{5}\end{array}$ & WDI \\
\hline Private Fixed Capital Formation & $\begin{array}{l}\text { Constant Local Currency Unit } \\
\text { (Rupees) in Millions }\end{array}$ & WDI \\
\hline Tax to GDP Ratio & Current Market Prices & Handbook of Statistics \\
\hline Government Current Expenditure & In Millions Rupees & Various Issues of ESP \\
\hline $\begin{array}{l}\text { Government Development Expen- } \\
\text { diture }\end{array}$ & In Millions Rupees & Various Issues of ESP \\
\hline $\begin{array}{l}\text { Government Total Expenditure to } \\
\text { GDP }\end{array}$ & Current Market Prices & Various Issues of ESP \\
\hline
\end{tabular}

${ }^{5}$ Rupee refers to Pakistani Currency

Similarly, the variables used in the empirical analysis and the way they are developed are given in Table 2.

Table 2: Variables' Definitions, Construction, and Explanation

\begin{tabular}{|c|c|c|}
\hline Variable's Definition & Construction of Variable & Explanation \\
\hline $\begin{array}{l}\text { Growth of Real GDP Per Capi- } \\
\text { ta (GPCI) }\end{array}$ & $\mathrm{GPCI}=\ln \mathrm{PCI}-\ln P C \mathrm{I}_{\mathrm{t}-1}$ & $\begin{array}{c}\text { Where } \ln P C I \text { is the natural log of } \\
\text { Real GDP Per Capita }\end{array}$ \\
\hline $\begin{array}{c}\text { Growth of Private Fixed Capital } \\
\text { Formation (GPFCF) } \\
\end{array}$ & $\mathrm{GPFCF}=\ln \mathrm{PFCF}-\ln \mathrm{PFCF}_{\mathrm{t}-1}$ & $\begin{array}{l}\text { Where lnFCF is natural log of } \\
\text { Private Fixed Capital Formation }\end{array}$ \\
\hline Ratio of tax to GDP (LTGDP) & LTGDP $=\ln$ TGDP & $\begin{array}{c}\text { Natural log of the ratio of tax to } \\
\text { GDP }\end{array}$ \\
\hline $\begin{array}{l}\text { Growth of Government Cur- } \\
\text { rent Expenditure (GCEX) }\end{array}$ & GCEX $=\operatorname{lnCEX}-\operatorname{lnCEX} X_{t-1}$ & $\begin{array}{l}\text { Where lnCEX is natural log of } \\
\text { government's current expendi- } \\
\text { ture }\end{array}$ \\
\hline $\begin{array}{l}\text { Growth of Government Devel- } \\
\text { opment Expenditure (GDEX) }\end{array}$ & $G D E X=\operatorname{lnDEX}-\operatorname{lnDEX} X_{t-1}$ & $\begin{array}{c}\text { Where } \operatorname{lnDEX} \text { is natural log } \\
\text { of government development } \\
\text { expenditure }\end{array}$ \\
\hline $\begin{array}{l}\text { Size of Public Spending } \\
\text { (GSIZE) }\end{array}$ & $\mathrm{GSIZE}=\ln (\mathrm{GSIZE})$ & $\begin{array}{c}\text { Where lnGSIZE is the natural } \\
\text { log of the ratio of total public } \\
\text { spending to GDP }\end{array}$ \\
\hline
\end{tabular}


To estimate this relationship between the variables of our interest, Auto regressive Distributed Lag (ARDL) model developed by Pesaran, Shin, and Smith (2001) is used as the variables are mixture of $I(0)$ and $I(1)$, therefore justifying use of the technique. Beside this, the employment of ARDL to the analysis is justified due to its several advantages over alternatives models of co-integration relationship such as the Engle and Granger (1987) and Johansen and Juselius (1990). These advantages of the model include: first, it is applicable irrespective of whether the underlying regressors are purely $I(0)$, purely $I(1)$ or mutually co-integrated. Second, besides this, it eliminates the uncertainty associated with pre-testing the order of integration, because bounds test does not depend on pre-testing the order of integration of the variables. In the literature of unit-root co integration, pre-testing is problematic due to low power of unit root tests and there is a switch in the distribution function of the test statistics as one or more roots of the $\mathrm{x}_{\mathrm{t}}$ (a time series) process approach unity (Pesaran \& Pesaran, 1997). Third, statistical properties of the unrestricted error correction model (UECM) are better than that of the two-step Engle-Granger method because the former method does not push the short-run dynamics into the residual terms (Banerjee, Dolado, Galbraith, \& Hendry, 1993). Fourth and last, the bounds test approach is applicable to studies based on small sample size (Narayan, 2004, 2005), whereas the Engle and Granger (1987) and Johansen $(1988,1995)$ methods of co-integration are not reliable.

To estimate both the long run and short run relationship between the composition of public expenditure and growth, ARDL method includes the following steps:

First, the following equation is estimated;

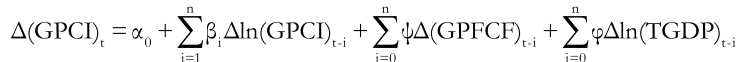

$$
\begin{aligned}
& +\sum_{i=0}^{n} \delta \Delta(\text { GCEX })_{t i-1}+\sum_{i=0}^{n} \pi \Delta(\text { GDEX) })_{t i-1}+\lambda_{1} \ln (\text { GPCI })_{t-1}+\lambda_{2}\left(\text { GPFCF }_{t=1}+\right. \\
& \lambda_{3} \ln (\mathrm{TGDP})_{\mathrm{t}-1}+\lambda_{4}(\mathrm{GCEX})_{\mathrm{t}-1}+\lambda_{5}(\mathrm{GDEX})_{\mathrm{t}-1}+\mu_{\mathrm{i}}
\end{aligned}
$$

In the model, GPCI is the growth of real GDP per capita, GPFCF is growth of private fixed capital formation, TGDP is tax to GDP ratio, GCEX is the growth of government current expenditure and GDEX is growth of development expenditure in Pakistan. The coefficients in the equation such as $\beta, \psi, \varphi, \delta$ and $\pi$ show the short run dynamics, while coefficients like $\lambda_{1}, \lambda_{2}, \lambda_{3}, \lambda_{4}$ and $\lambda_{5}$ represents the long run relationship in the model. Then the null and alternative hypotheses are tested via F-statistic or standard Wald statistic as:

$$
\begin{aligned}
& \mathrm{H}_{0}: \lambda_{1}=\lambda_{2}=\lambda_{3}=\lambda_{4}=\lambda_{5}=0 \text { (no Co-integration relationship) } \\
& \mathrm{H}_{1}: \lambda_{1} \neq \lambda_{2} \neq \lambda_{3} \neq \lambda_{4} \neq \lambda_{5} \neq 0
\end{aligned}
$$

In case of rejection of the null hypothesis, the next step would be to estimate the long-run parameters via equation (2) and the short-run dynamics [the Error Correction 
Model (ECM)] via equation (3) respectively;

$$
\begin{aligned}
& \text { GPCI }_{t}=\alpha_{0}+\sum_{\mathrm{i}=1}^{\mathrm{n}} \beta_{\mathrm{i}}(\mathrm{GPCI})_{\mathrm{t}-\mathrm{i}}+\sum_{\mathrm{i}=0}^{\mathrm{n}} \psi(\mathrm{GPFCF})_{\mathrm{t}-\mathrm{i}}+\sum_{\mathrm{i}=0}^{\mathrm{n}} \varphi \ln (\mathrm{TGDP})_{\mathrm{t}-\mathrm{i}}+\sum_{\mathrm{i}=0}^{\mathrm{n}} \delta(\mathrm{GCEX})_{\mathrm{t}-\mathrm{i}} \\
& +\sum_{\mathrm{i}=0}^{\mathrm{n}} \pi(\mathrm{GDEX})_{\mathrm{t}-\mathrm{i}}+\mu_{\mathrm{i}}
\end{aligned}
$$

The Error Correction Model involves estimation of the following equation;

$$
\begin{aligned}
& \Delta(\mathrm{GPCI})_{\mathrm{t}}=\alpha_{0}+\sum_{\mathrm{i}=1}^{\mathrm{n}} \beta_{\mathrm{i}} \Delta(\mathrm{GPCI})_{\mathrm{t}-\mathrm{i}}+\sum_{\mathrm{i}=0}^{\mathrm{n}} \psi \Delta(\mathrm{GPFCF})_{\mathrm{t}-\mathrm{i}}+\sum_{\mathrm{i}=0}^{\mathrm{n}} \varphi \Delta \ln (\mathrm{TGDP})_{\mathrm{t}-\mathrm{i}} \\
& +\sum_{\mathrm{i}=0}^{\mathrm{n}} \delta \Delta(\mathrm{GCEX})_{\mathrm{t}-\mathrm{i}}+\sum_{\mathrm{i}=0}^{\mathrm{n}} \pi \Delta(\mathrm{GDEX})_{\mathrm{t}-\mathrm{i}}+\eta(\mathrm{ECM})_{\mathrm{t}-1}+\mu_{\mathrm{i}}
\end{aligned}
$$

Similarly, to estimate the long run relationship between the size of public expenditure and economic growth, the following equation will be used;

$$
\begin{aligned}
& \mathrm{GPCI}_{\mathrm{t}}=\alpha_{0}+\sum_{\mathrm{i}=1}^{\mathrm{n}} \beta_{\mathrm{i}}(\mathrm{GPCI})_{\mathrm{t}-\mathrm{i}}+\sum_{\mathrm{i}=0}^{\mathrm{n}} \psi(\mathrm{GPFCF})_{\mathrm{t}-\mathrm{i}}+\sum_{\mathrm{i}=0}^{\mathrm{n}} \varphi \ln (\mathrm{TGDP})_{\mathrm{t}-\mathrm{i}} \\
& +\sum_{\mathrm{i}=0}^{\mathrm{n}} \delta \ln (\mathrm{GSIZE})_{\mathrm{t}-\mathrm{i}}+\mu_{\mathrm{i}}
\end{aligned}
$$

And to estimate short run parameters the following equation will be used;

$$
\begin{aligned}
& \Delta(\mathrm{GPCI})_{\mathrm{t}}=\alpha_{0}+\sum_{\mathrm{i}=1}^{\mathrm{n}} \beta_{\mathrm{i}} \Delta(\mathrm{GPCI})_{\mathrm{t}-\mathrm{i}}+\sum_{\mathrm{i}=0}^{\mathrm{n}} \psi \Delta(\mathrm{GPFCF})_{\mathrm{t}-\mathrm{i}}+\sum_{\mathrm{i}=0}^{\mathrm{n}} \psi \Delta \ln (\mathrm{TGDP})_{\mathrm{t}-\mathrm{i}} \\
& +\sum_{\mathrm{i}=0}^{\mathrm{n}} \delta \Delta \ln (\mathrm{GSIZE})_{\mathrm{t}-\mathrm{i}}+\eta(\mathrm{ECM})_{\mathrm{t}-1}+\mu_{\mathrm{i}}
\end{aligned}
$$

To determine the goodness of fit of ARDL, the diagnostic tests including normality, serial correlation, functional form, and heteroscedasticity have been conducted.

\section{Analysis and Results}

To proceed empirical analysis of the models, Augmented Dickey-Fuller (ADF) and Phillips-Perron (PP) tests are conducted to check the stationarity of each variable and the results are shown in Table 3 based on ADF, while that of PP are given in Table 4.

Table 3: Unit Root Estimation Based on ADF Test

\begin{tabular}{|c|c|c|c|c|}
\hline \multirow{2}{*}{ Variables } & \multicolumn{4}{|c|}{ Augmented Dickey Fuller (ADF) Test } \\
\cline { 2 - 5 } & \multicolumn{2}{|c|}{ With drift } & \multicolumn{2}{c|}{ With drift \& trend } \\
\cline { 2 - 5 } & Level & 1 st Difference & Level & 1st Difference \\
\hline GPCI & $-4.711^{*}$ & $-9.998^{*}$ & $-4.838^{*}$ & $-9.861^{*}$ \\
\hline GPFCF & $-4.766^{*}$ & $-8.845^{*}$ & $-5.544^{*}$ & $-8.819^{*}$ \\
\hline TGDP & -1.829 & $-7.185^{*}$ & -2.246 & $-7.135^{*}$ \\
\hline GCEX & $-5.965^{*}$ & $-9.682^{*}$ & $-5.905^{*}$ & $-9.613^{*}$ \\
\hline GDEX & $-6.978^{*}$ & $-7.769^{*}$ & $-6.864^{*}$ & $-7.846^{*}$ \\
\hline GSIZE & -1.453 & $-6.509^{*}$ & -2.567 & $-6.422^{*}$ \\
\hline
\end{tabular}

Notes: ${ }^{*},{ }^{* *},{ }^{* *}$ represents significant at $1 \%, 5 \%$ and $10 \%$ level of significance respectively. 
The application of ARDL model to the analysis is justified on the basis of mixture of $I(0)$ and $I(1)$ of the variables in the model. From both the tests, it is evident that economic growth proxied by real GDP per Capita (GPCI), growth of private fixed capital formation (GPFCF), growth of current expenditure (GCEX) and growth of development expenditure (GDEX) are stationary at level, while tax to GDP ratio (TGDP) and government size (GSIZE) become stationary at first difference.

Table 4: Unit Root Estimation Based on Philips-Perron Test

\begin{tabular}{|c|c|c|c|c|}
\hline \multirow{2}{*}{ Variables } & \multicolumn{2}{|c|}{ With drift } & \multicolumn{2}{c|}{ With drift \& trend } \\
\cline { 2 - 5 } & Level & 1st Difference & Level & 1st Difference \\
\hline GPCI & $-4.680^{*}$ & $-14.464^{*}$ & $-4.808^{*}$ & $-14.251^{*}$ \\
\hline GPFCF & $-4.784^{*}$ & $-19.990^{*}$ & $-5.531^{*}$ & $-19.509^{*}$ \\
\hline TGDP & -1.724 & $-7.260^{*}$ & -2.322 & $-7.217^{*}$ \\
\hline GCEX & $-5.965^{*}$ & $-12.549^{*}$ & $-5.898^{*}$ & $-12.564^{*}$ \\
\hline GDEX & $-6.962^{*}$ & $-16.673^{*}$ & $-6.852^{*}$ & $-17.187^{*}$ \\
\hline GSIZE & -1.444 & $-6.509^{*}$ & -2.755 & $-6.422^{*}$ \\
\hline
\end{tabular}

Notes: ${ }^{*},{ }^{*},{ }^{* *}$ represents significant at $1 \%, 5 \%$ and $10 \%$ level of significance respectively.

After stationarity checking, F-statistic is computed based on Akaike Information Criterion $(\mathrm{AIC})^{5}$ via EViews 9 software. The calculated F-statistic $(F$-stat $=4.68)$ based on AIC criterion is greater than the upper bound critical value $[I(1)=4.01]$ at $5 \%$ level of significance and hence the null hypothesis is rejected, thereby confirming the existence of long run equilibrium relationship between economic growth (the dependent variable) and the set of explanatory variables.

Similarly, the long run and short run estimates of the model are given in Table 6 and ${ }^{7}$ respectively. The results show that as compared to current public expenditure, development expenditures are growth-oriented in case of Pakistan. Every 1\% increase in the growth of development expenditure (GDEX) leads to an increase of $0.031 \%$ in growth of real per capita income (GPCI) on average, where as that of current expenditure (GCEX) reduces economic growth by $0.084 \%$ on average and both the coefficients are statistically significant at 10 and 5 percent respectively. Our results confirm the claims of Aschauer (1989) and Barro (1991), who are of the opinion that productive expenditures are growth enhancing, while current are not. Interestingly, private investment is more growth-oriented as compared to public investment and the impact of growth of private fixed capital formation (GPFCF) on economic growth is positive with 0.120 on average in the long run and is significant at $5 \%$.

5 Model selection summary is given appendix no.1 
Table 5: Bound Test of Expenditure Composition-Economic Growth Model

\begin{tabular}{|c|c|c|}
\hline \multicolumn{2}{|c|}{ F-Statistics (Wald-Test) =4.68; based on AIC Criterion } \\
\hline Level of Significance & Lower Bound Value I(0) & Upper Bound Value I(1) \\
\hline $1 \%$ & 3.74 & 5.06 \\
\hline $5 \%$ & 2.86 & 4.01 \\
\hline $10 \%$ & 2.45 & 3.52 \\
\hline
\end{tabular}

$R^{2}=0.423 \quad$ F-Statistics $=4.027$ Prob $(0.004)$

Adj. $R^{2}=0.318$ Durbin-Watson Stat $=2.139$

Table 6: Estimated Long Run Coefficients of Public Spending Composition Model

\begin{tabular}{|c|c|c|c|c|}
\hline \multicolumn{5}{|c|}{ ARDL (1,0, 0, 1, 0) based on AIC (F-stat $=4.68)$ Dependent Variable (GPCI) } \\
\hline Variable & Coefficient & Std. Error & t-Statistic & Prob. \\
\hline GPFCF & 0.120 & 0.050 & 2.417 & 0.021 \\
\hline LTGDP & 0.004 & 0.022 & 0.195 & 0.847 \\
\hline GCEX & -0.084 & 0.037 & -2.281 & 0.029 \\
\hline GDEX & 0.031 & 0.016 & 1.942 & 0.061 \\
\hline C & 0.015 & 0.052 & 0.284 & 0.778 \\
\hline
\end{tabular}

Table 7: Estimated Short Run Coefficients of Public Spending Composition Model

\begin{tabular}{|c|c|c|c|c|}
\hline \multicolumn{6}{|c|}{ ARDL $(\mathbf{1 , 0 , 0 , 1 , 0 )}$ based on AIC Dependent Variable $(\mathbf{G P C I})$} \\
\hline Variable & Coefficient & Std. Error & t-Statistic & Prob. \\
\hline$\Delta$ GPFCF $_{\mathrm{t}}$ & 0.114 & 0.053 & 2.156 & 0.038 \\
\hline$\Delta$ LTGDP $_{\mathrm{t}}$ & 0.004 & 0.021 & 0.195 & 0.847 \\
\hline$\Delta \mathrm{GCEXt}_{\mathrm{t}}$ & -0.037 & 0.025 & -1.499 & 0.143 \\
\hline$\Delta \mathrm{GDEX}_{\mathrm{t}}$ & 0.029 & 0.014 & 2.091 & 0.044 \\
\hline ECM $_{\mathrm{t}-1}$ & -0.946 & 0.163 & -5.794 & 0.000 \\
\hline
\end{tabular}

The short run results of the model are shown in Table 7 . The sign and significance of the ECM term shows causality in at least one way and in our analysis it is negative and highly significant. The coefficient of $\mathrm{ECM}\left(\mathrm{ECM}_{\mathrm{t}-1}=-0.946\right)$ shows that $94.6 \%$ of the deviations from the long run equilibrium are corrected each year after a shock occurs. Besides these, a number of diagnostic tests are also conducted and shown in Table 8. From the tests, the problems of heteroscedasticity and serial correlation in the disturbances are not found. Similarly, specification and normality tests are conducted which indicate that the model is correctly specified and the errors are normally distributed. 
Table 8: Diagnostic Checking for of Public Spending Composition Model Based on AIC

\begin{tabular}{|c|c|c|c|}
\hline Problem & Test-Statistics & Probability & Conclusion \\
\hline Normality & Jarque-Bera $=0.224$ & 0.894 & Normality Exists \\
\hline Serial Correlation & $\begin{array}{c}\text { Breusch-Godfrey LM } \\
\text { Test }=1.016\end{array}$ & $\mathrm{~F}(1,32)=0.321$ & No Serial Correlation \\
\hline Heteroskedasticity & $\begin{array}{c}\text { Breusch-Pagan-God- } \\
\text { frey=1.566 }\end{array}$ & $\mathrm{F}(6,33)=0.188$ & No Heteroskedasticity \\
\hline Specification & Ramsey RESET $=0.284$ & $\mathrm{~F}(1,32)=0.598$ & Correctly Specified \\
\hline
\end{tabular}

In order to test the hypothesis of no co-integration relationship between government size and economic growth, F-statistic is calculated based on AIC criterion ${ }^{6}$. The value of calculated F-statistic $($ F-stat $=5.133)$ is greater than the upper bound critical value $[I(1)=4.35]$ at $5 \%$ level of significance and hence the null hypothesis is rejected.

Similarly, the long run and short run estimates of the model are shown in Table 9 and 10 respectively. The results indicate that size of government's expenditures negatively affects growth in case of Pakistan. Every $1 \%$ increase in size of public expenditure reduces growth of real GDP per capita by $0.057 \%$ on average. Our findings are inconformity with the findings of Barro (1991), Folster and Henrekson (2001), Romero de Avila and Strauch (2003), and Schaltegge and Torgler (2006). The reason of negative relationship between government size and economic growth in Pakistan may be attributed to the allocation of huge amount to current expenditures which are not growth-oriented and remained about $80 \%$ on average of the total government expenditures over the last decade. Another plausible reason seems to be the allocation of huge amount to debt servicing and debt repayment. This is evident from the fact that during July-March, 2014-15, debt servicing consumed nearly $44.5 \%$ of total revenues against a ratio of $47 \%$ during the same period last year (ESP, 2014-15).

From the short run results, the coefficient of $\mathrm{ECM}\left(\mathrm{ECM}_{\mathrm{t}-1}=-0.951\right)$ shows that $95.1 \%$ of the deviations from the long run equilibrium are corrected each year after a shock occurs. Besides these, a number of diagnostic tests are also conducted and shown in Table 11. From the tests, the problems of heteroscedasticity and serial correlation in the disturbances are not found. Similarly, specification and normality tests are conducted which indicate that the model is correctly specified and the errors are normally distributed.

\section{Conclusion and Policy Recommendations}

The role of government in influencing the lives of the people through its socio-eco-

6 Model selection summary is given in appendix no.2. 
nomic policies cannot be denied in the present era. The range of economic policies is not even large, but also diverse and often very complex in nature(Tanzi, 2006). The purpose of this study is to empirically investigate the relationship between the composition of public spending and economic growth in Pakistan on the one hand and the impact of size of public expenditure on growth on the other hand. Fiscal Policy is expected to pursue a variety of goals including economic growth, equitable distribution of wealth, the provision of public goods and the like. However, in this study the focus is to identify the growth-oriented components of public expenditure as it seems useful to know the contribution of each component of spending to the objective of economic growth. The current study is categorical in empirical sense in that it takes government expenditures as consumption (unproductive) and development expenditure (productive) as reported in annual budget statements of government of Pakistan. While the study adopts Kocherlakota and Yi (1997) model as modified by Colombier (2008) to carry out empirical analysis with slight modification based on the availability of the relevant data. To estimate this relationship between the variables of our interest, ARDL model developed by Pesaran et al. (2001) has employed.

The results indicate long-run relationship between economic growth proxied by growth of real GDP per capita (GPCI) and set of explanatory variables including growth of private fixed capital formation (GPFCF), tax to GDP ratio (TGDP), growth of current expenditure (GCEX) and growth of development expenditure (GDEX). The results show that development expenditure enhances economic growth in Pakistan, while current expenditure reduces it. Similarly, overall government expenditure (size of government proxied by the ratio of total public expenditure to GDP) reduces growth due to the negative effect of the major component that is current spending with in total government expenditure. Our results confirm the opinion of Devarajan et al. (1996), according to which marginal efficiency of fund falls with allocation of excessive amount for productive/unproductive purposes.

The dream of sustainable economic growth and sustainable development can only be materialized by changing the composition of public spending in favor of development expenditure. Since the country is in dire need of infrastructure and energy, therefore allocation of more funds to Public Sector Development Programs (PSDP) are expected to add directly to growth on one hand and set crowding-in effect for private investment thereby enhancing growth indirectly on the other hand.

\section{References}

Afridi, A. H. (2016). Human capital and economic growth of Pakistan. Business Eु Economic Review, 8(1), 77-86. 
Aarle, B. V. (2013). Structural reforms and fiscal adjustments: Policy options for the euro area. Journal of Economic Policy Reform, 16(4), 320-335.

Agell, J., Lindh, T., \& Ohlsson, H. (1997). Growth and the public sector: A critical review essay. European Journal of Political Economy, 13(1), 33-52.

Agell, J., Lindh, T., \& Ohlsson, H. (1999). Growth and the public sector: a reply. European Journal of Political Economy, 15(2), 359-66.

Alam, S., Sultana, A., \& Butt, M. S. (2010). Does social expenditures promote economic growth ? A multivariate panel cointegration analysis for asian countries. European Journal of Social Sciences, 14(1), 44-54.

Arrow, K. J., \& Kurz, M. (1970). Public investment, the rate of return and optimal fiscal policy. Baltimore, MD: Johns Hopkins University.

Aschauer, D. A. (1989). Is public expenditure productive? Journal of Monetary Economics, 23(2), 177-200.

Atkinson, A. B. (1995). The welfare state and economic performance. National Tax Journal, 48 ( 2 ), $171-98$.

Atkinson, A. B., \& Stiglitz, J. E. (1976). The design of tax structure: direct vs. indirect taxation. Journal of Public Economics 6(1-2), 55-75.

Banerjee, A., Dolado, J. J., Galbraith, J. W., \& Hendry, D. F. (1993). Co-integration, error correction and the econometric analysis of non-stationary data. Oxford University Press: Oxford.

Barbiero, O., \& Cournède, B. (2013). New econometric estimates of long-term growth effects of different areas of public spending. OECD Economics Department Working Papers No. 1100, OECD Publishing.

Barnes, B. J. (2008). A Cointegrating approach to budget deficits and long-term interest rates. Applied Economics, 40(2), 127-133.

Barrios, S., \& Schaechter, A. (2008). The quality of public finances and economic growth, European Economy, Economic Papers 337, September, 2008, Brussels, 50pp.

Barro, R. J. (1990). Government spending in a simple model of endogenous growth. Journal of Political Economy, 98(5/2), 103-126.

Barro, R. J. (1991). Economic growth and a cross section of countries. Quarterly Journal of Economics, 106(2), 407-441.

Barro, R. J., \& Sala-i-Martin, X. (1992). Public finance in models of economic growth. Review of Economic Studies, 59(4), 645-661.

Barro, R. J., \& Sala-i-Martin, X. (1995). Economic growth. McGraw-Hill: New York.

Birchwood, A., \& Matthias, R. (2007). Structural factors associated with primary fiscal balances in 
developing countries. Applied Economics, 39(10), 1235-1243.

Blazek, J., \& Macešková, M. (2010). Regional analysis of public capital expenditure: To which regions is public capital expenditure channeled - to 'rich' or to 'poor' ones? Regional Studies, 44(6), 679-696.

Boadway, R., \& Marchand, M. (1995) The use of public expenditure for redistributive purposes. Oxford Economic Papers 47, 45-59.

Bose, N., Haque, E., \& Osborn, D. (2007). Public expenditure and economic growth: A disaggregated analysis for developing countries. The Manchester School, 75(5), 533-556.

Chamorro-Narvaez, R. A. (2012). The composition of government spending and economic Growth in developing countries: The case of Latin America. International Journal of Sustainable Development, 5(6), 39-50.

Chu, K-Y., Davoodi, H., \& Gupta, S. (2004). Income Distribution and Tax and Government Social Spending Policies in Developing Countries, in Inequality, Growth, and Poverty in an Era of Liberalization and Globalization, ed. by Giovanni Andrea Cornia (New York: Oxford University Press).

Colombier, C. (2008). Government and growth, group of economic advisors -Swiss federal finance administration, Working Paper No.4.

Colombier, C. (2011). Does the composition of public expenditure affect economic growth? Evidence from the Swiss case. Applied Economics Letters, 18(16), 1583-1589.

Costa, D. J., Ellson, R. W., \& Martin, R. C. (1987). Public capital, regional output and developments: Some empirical evidence. Journal of Regional Science, 27(3), 419-437.

Deno, K. T. (1988). The effect of public capital on U.S. manufacturing activity: 1970 to 1978. Southern Economic Journal, 55(1), 400-411.

Devarajan, S., Swaroop, V., \& Zou, H. F. (1996). The composition of public expenditure and economic growth. Journal of Monetary Economics, 37(2), 313-344.

Easterly, W., \& Rebelo, S. (1993). Fiscal policy and economic growth: An empirical Investigation. Journal of Monetary Economics, 32(3), 417-58.

Engle, R. F., \& Granger, C. W. J. (1987). Co-integration and error correction: Representation, estimation and testing. Econometrica, 55, 251-76.

Ferreiro, J., Valle, M. G. D., \& Gomez, C. (2012). Similarities and differences in the composition of public expenditures in the European Union. Journal of Economic Issues, 46(3), 633-660.

Folster, S., \& Henrekson, M. (2001). Growth effects of government expenditure and taxation in rich countries. European Economic Review, 45(8), 1501-20.

Gemmell, N., \& Kneller, R. (2001). The impact of fiscal policy on long-run growth. European Economy: Reports and Studies, 1, 97-129. 
Ghani, E., \& Din, M. (2006). The impact of public investment on economic growth in Pakistan. The Pakistan Development Review, 45(1), 87-98.

Government of Pakistan, Ministry of Finance. Economic Survey of Pakistan (2012-13). Islamabad: Ministry of Finance; 2012-13.

Government of Pakistan, Ministry of Finance. Economic Survey of Pakistan (2014-15). Islamabad: Ministry of Finance; 2014-15.

Gupta, S., \& Verhoeven, M., (2001). The efficiency of government expenditure experiences from Africa. Journal of Policy Modeling, 23(4), 433-467.

Haque, M., \& Kim, D. (2003). Public investment in transportation and communication and growth: A dynamic panel approach. University of Manchester. Discussion Paper Series, No. 031.

Hyder, K. (2001). Crowding-out hypothesis in a vector error correction framework: A case study of Pakistan. The Pakistan Development Review, 40(4), 633-650.

Irmen, A., \& Kuehnel, J. (2009). Productive government expenditure and economic growth. Journal of Economic Surveys 23(4), 692-733.

Johansen, S. (1988). Statistical analysis of co-integration vectors. Journal of Economic Dynamics and Control, 12(2-3), 231-254.

Johansen, S., \& Juselius, K. (1990). Maximum likelihood estimation and inference on co-integration with applications to the demand for money. Oxford Bulletin of Economics and Statistics, 52(2), 169-210.

Khan, M. S. (1996). Government investment and economic growth in the developing world. The Pakistan Development Review, 35(4), 419-439.

King, R. G., \& Rebelo, S. (1990). Public policy and economic growth: Developing neoclassical implications. Working Paper No. 3338, National Bureau of Economic Research, Cambridge, MA.

Kocherlakota, N. R., \& Yi, K. M. (1997). Is there endogenous long-run growth? Evidence from the United States and the United Kingdom. Journal of Money, Credit and Banking, 29(2), 235-62.

Looney, R. E. (1995). Public sector deficits and private investment: A test of the crowding-out hypothesis in Pakistan's manufacturing industry. The Pakistan Development Review, 34(3), 277-292.

Lucas, R. (1988). On the mechanic of economic development. Journal of Monetary Economics, 22(1), 4-42.

Magdalena, R., Logica, B., \& Zamfiroiu, T. (2015). Forecasting public expenditure by using feed-forward neural networks. Economic Research-Ekonomska Istrazivanja, 28(1), 668-686.

Mehmood, R., \& Sadiq, S. (2010). The relationship between government expenditure and poverty: A co-integration analysis. Romanian Journal of Fiscal Policy, 1(1), 29-37.

Milbourne, R., Otto, G., \& Voss, G. (2003). Public investment and economic growth. Applied Economics, 35(5), 527-540. 
Musgrave, R.A. (1997). Reconsidering the fiscal role of government. American Economic Review, 87(2), 156-159.

Musgrave, R. A., \& Musgrave, B. P. (1973). Public finance in theory and practice. Kogakusha, Tokyo: McGraw-Hill.

Naqvi, N. H. (2002). Crowding-in or crowding-out? Modelling the relationship between public and private fixed capital formation using co-integration analysis: The case of Pakistan 1964-2000. The Pakistan Development Review, 41(3), 255-276.

Narayan, P. K. (2004). Reformulating critical values for the bounds F-statistics approach to co-integration: An application to the tourism demand model for Fuji. Discussion papers, department of economics, Monash University, Australia.

Narayan, P. K. (2005). The saving and investment nexus for China: Evidence from co-integration tests. Applied Economics, 37(17), 1979-1990.

Nijkamp, P., \& Poot, J. (2003). Meta-analysis of the effect of fiscal policies on long-run growth. European Journal of Political Economy, 20(1), 91-124.

Olabisi, A. S., \& Oloni, E. F. (2012). Composition of public expenditure and economic growth in Nigeria. Journal of Emerging Trends in Economics and Management Sciences, 3(4), 403-407.

Overman, S., \& Van Thiel, S. (2016). Agencification and public sector performance: A systematic comparison in 20 countries. Public Management Review, 18(4), 611-635.

Pesaran, H. M., \& Pesaran, B. (1997). Working with Microfit 4.0: Interactive econometric analysis. England: Oxford University Press.

Pesaran, H. M., Shin, Y., \& Smith, R. J. (2001). Bounds testing approaches to the analysis of level relationships. Journal of Applied Econometrics, 16(3), 289-326.

Porteous, D. J. (1995). The geography of finance. Aldershot: Avebury, 11, 112-156.

Qasim, A. W., Kemal, M. A., \& Siddique, O. (2015). Fiscal consolidation and economic growth: A case study of Pakistan. Pakistan Institute of Development Economics (PIDE), Working Paper No.124, Islamabad, Pakistan.

Romer, P. M. (1986). Increasing returns and long-run growth. Journal of Political Economy, 94(5), 1002-37.

Romer, P. M. (1990). Are non-convexities Important for Understanding Growth? American Economic Growth, 80, 97-103.

Romero de Avila, D., \& Strauch, R. (2003). Public finances and long-term growth in Europe - evidence from a panel data analysis. ECB Working Paper No. 246.

Schaltegger, C. A., \& Torgler, B. (2006). Growth effects of public expenditure on the state and local level: Evidence from a sample of rich governments. Applied Economics, 38(10), 1181-1192. 
Solow, R. M. (1956). A Contribution to the theory of economic growth. Quarterly Journal of Economics, 70(1), 65-94.

Swan, T. (1956). Economic growth and capital accumulation. Economic Record, 32(2), 334-361.

Tanzi, V. \& Zee, H. H. (1997). Fiscal policy and long-run growth. IMF Staff Papers, 44(2), 179-209.

Tanzi, V. (2006).Fiscal policy: When theory collides with reality. Centre for European Policy Studies (CEPS) Working Documents No. 246/June, 2006.

Wang, Q., \& Wang, W. (2014). An analysis of Chinese government expenditure using dynamic binary panel data. Applied Economics, 46(11), 1259-1266.

Yaya, K. (2010). Budget deficits and economic growth: Causality evidence and policy implications for WAEMU countries. European Journal of Economics, Finance and Administrative Sciences, 18, 99-104.

Zafar, Z., \& Mustafa, Z. (1998). Macroeconomic determinants of economic growth in Pakistan. The Pakistan Development Review, 37(2), 125-148. 